\title{
The place for electroconvulsive therapy in the management of behavioral and psychological symptoms of dementia
}

\author{
Rajesh R Tampi*i, ${ }^{*}$, Deena J Tampi ${ }^{3}$, Juan Young ${ }^{4}$, Rakin Hoq ${ }^{5}$ \& Kyle Resnick ${ }^{5}$ \\ ${ }^{1}$ Department of Psychiatry \& Behavioral Sciences, Cleveland Clinic Akron General, Akron, OH 44307, USA \\ ${ }^{2}$ Cleveland Clinic Lerner College of Medicine of Case Western Reserve University, Cleveland, OH 44195, USA \\ ${ }^{3}$ Diamond Healthcare, Richmond, VA 23219, USA \\ ${ }^{4}$ Department of Psychiatry, Yale School of Medicine, New Haven, CT 06510, USA \\ ${ }^{5}$ Summa Health Systems/NEOMED Psychiatry Residency Program, Akron, OH 44304, USA \\ *Author for correspondence: Tel.: +1 203809 5223; Fax: +1 330344 2943; rajesh.tampi@gmail.com
}

"ECT appears to be a safe treatment among older adults with few contraindications and transient
or limited number of adverse effects"

First draft submitted: 26 August 2019; Accepted for publication: 4 October 2019; Published online: 8 November 2019

Keywords: behavioral and psychological symptoms of dementia (BPSD) • disruptive vocalization • electroconvulsive therapy $(\mathrm{ECT}) \bullet$ neuropsychiatric symptoms $\bullet$ physical aggression $\bullet$ postictal confusion

The term 'behavioral and psychological symptoms of dementia' (BPSD) is used to describe a group of noncognitive symptoms and behaviors that are commonly seen among individuals with dementia. BPSD occurs among a third to three-quarters of individuals with dementia, with greater prevalence seen among individuals living in institutional settings [1]. In addition to causing significant emotional distress to the individuals with dementia and their caregivers, BPSD is also associated with significant negative effects including a decline in cognition and function among individuals with dementia, lower the quality of life for individuals with dementia and their caregivers, greater rates of institutionalization for individuals with dementia and greater financial burden to the families of individuals with dementia and the society in general [1].

Available evidence indicates that both non-pharmacological and pharmacological interventions are beneficial for the management of BPSD [2]. Pharmacotherapy is usually reserved for those symptoms or behaviors that are refractory to non-pharmacological interventions. In addition, pharmacotherapy is typically used in combination with non-pharmacological interventions for the management of BPSD. Caregiver and staff education along with cognitive stimulation appears to have sustained benefits in the management of BPSD [3]. Current evidence indicates efficacy for antidepressants, anticonvulsants, antipsychotics and cholinesterase inhibitors for the management of BPSD. However, the use of psychotropic medications, especially antipsychotics, for management of BPSD has come under scrutiny due to their significant adverse effects, including cerebrovascular adverse events and death [4].

Electroconvulsive therapy (ECT) is an important treatment tool among older adults with psychiatric disorders [57]. Evidence indicates efficacy for ECT in the treatment of depression, mania, psychosis and catatonia. It is has been found to be highly effective in emergency situations like malignant catatonia, depression with psychotic or catatonic features and among individuals with threatening suicidal behaviors. ECT also appears to have greater benefit among older adults when compared with younger adults [6]. In addition, ECT appears to be a safe treatment among older adults with few contraindications and transient or limited number of adverse effects.

Over the past two decades, there has been growing interest in using ECT among individuals with BPSD [8]. In this article, we review the evidence for using ECT in the management of BPSD. Based on the available evidence, we make recommendations on when the use of ECT is appropriate among individuals with BPSD. We searched the databases PubMed and Ovid Medline using two keywords: 'ECT' and 'dementia'. In addition, we also reviewed the references of included studies for additional papers. We only included published studies that evaluated the use of ECT for BPSD in this report, irrespective of the type of study. 


\section{Evidence for using ECT in the management of BPSD}

A review of the literature indicates that there are 20 published reports on the use of ECT for the management of BPSD [9-28]. These reports included a total of 172 individuals with dementia. A majority of these studies were case reports (eight of 20,40\%) followed by retrospective chart reviews (five, 25\%) and case series (four, 20\%). There was only one prospective cohort study [23], one case-control study [24] and one prospective observational study [27]. A majority of the individuals had Alzheimer's disease (68 of 172, 40\%) followed by unspecified dementia (25, 15\%) and vascular dementia $(22,13 \%)$. Bitemporal followed by right unilateral and bilateral were the most common electrode placements. Twelve of the studies (60\%) were reported from the US followed by four from Canada and one each from The Netherlands, Germany, Italy and China. It appears that over $90 \%$ of the individuals who were treated with ECT responded to treatment with a resolution of target symptoms including verbal and physical aggression and suicidal behaviors. Adverse effects from the ECT were infrequent and when they did occur, were mild and transient. The most common adverse event that was reported was postictal confusion/memory impairment in approximately $25(15 \%)$ of the individuals. Table 1 provides details of these published papers obtained via a literature search.

Although the therapeutic mechanism of ECT is unclear, it is postulated that ECT benefit individuals with BPSD by enhancing the transmission of neurochemicals including GABA, glutamate, dopamine and norepinephrine in the brain [29-33].

Two recent systematic reviews have evaluated the literature on the use of ECT for the management of BPSD. In the first review, Glass et al. found 11 papers that included a total of 216 individuals with BPSD who were treated with ECT [34]. The authors reported that despite being limited to case reports, case series, retrospective chart review, retrospective case-control and an open-label prospective study, ECT demonstrated promise in reducing agitation among individuals with dementia. Additionally, in those individuals who had a relapse in symptoms, they found benefit from maintenance ECT. In the second systematic review by van den Berg et al., the authors found 17 reports that evaluated the use of ECT among individuals with BPSD [35]. The investigators reported that they found one prospective cohort study and one case-control study, whereas the others were retrospective chart reviews, case series or case reports. They reported that clinically significant improvement was observed in $88 \%$ of the 122 individuals in these studies and the effect was often noted early in the treatment course. Additionally, the adverse effects were most often mild, transient or not reported.

Two recent reports also indicate that ECT does not increase the risk of dementia [36,37]. Additionally, there is no evidence that ECT worsens cognition among individuals with dementia [38-40].

The findings of this report are similar to the two above-mentioned systematic reviews. There is emerging evidence that ECT appears to be beneficial in treating individuals with BPSD and is fairly well tolerated. However, the major limitations of available data are as mentioned in the two systematic reviews - there is substantial risk of selection bias in these studies, the study designs are not randomized controlled trials, and there are a limited number of studies with few participants available in the literature.

\section{Place for using ECT in the management of BPSD}

Based on the available evidence from a search of the literature, it is our opinion that ECT appears to be a viable treatment option for individuals with BPSD. It appears to be particularly suited for use among individuals who have had an inadequate response to non-pharmacological and pharmacological treatment strategies, among those individuals who have tolerability issues to pharmacotherapy, and also among those individuals in whom there is a need for the quick resolution of symptoms for their safety and well being.

We agree with Burgut $e$ al. who caution that the decision to use ECT among individuals with BPSD should be done after a thoughtful review of all available treatment options [8]. The authors remind us that the use of ECT among individuals with BPSD would be an 'off-label' indication. They further caution us that ECT remains a controversial treatment in medicine, not due to any clinical or scientific evidence regarding its efficacy and safety, but due to societal misperception about its use among patients with mental health disorders. The authors recommend the use of ECT among individuals with BPSD only when all other treatment options have failed, and with the informed consent of the individual with dementia or their surrogate decision makers who are fully appraised of the potential risks of the treatment. The authors also recommend ongoing risk-benefit analysis of the treatment trial to maximize gains and reduce harm from the ECT treatments. 
Table 1. Summary of published studies on the use of electroconvulsive therapy for the management of behavioral and psychological symptoms of dementia.

\begin{tabular}{|c|c|c|c|c|c|c|c|c|c|}
\hline Study (year) & Country & Type of study & $\begin{array}{l}\text { Number of } \\
\text { patients }\end{array}$ & $\begin{array}{l}\text { Type of } \\
\text { patients }\end{array}$ & Type of ECT & Target behaviors & Outcomes & Adverse effects & Ref. \\
\hline $\begin{array}{l}\text { Carlyle et al. } \\
\text { (1991) }\end{array}$ & Canada & Case series & 3 & $\begin{array}{l}\text { Dementia, } \\
\text { type not } \\
\text { specified }\end{array}$ & Bilateral & $\begin{array}{l}\text { Verbal } \\
\text { aggression } \\
\text { (disruptive } \\
\text { vocalizations) }\end{array}$ & $\begin{array}{l}\text { Improvement in } \\
\text { symptoms }\end{array}$ & None reported & [9] \\
\hline $\begin{array}{l}\text { Holmberg et al. } \\
\text { (1996) }\end{array}$ & USA & Case report & 1 & $\begin{array}{l}\text { Dementia, } \\
\text { type not } \\
\text { specified }\end{array}$ & Bilateral & $\begin{array}{l}\text { Verbal and } \\
\text { physical } \\
\text { aggression }\end{array}$ & $\begin{array}{l}\text { Improvement in } \\
\text { symptoms }\end{array}$ & None reported & [10] \\
\hline $\begin{array}{l}\text { Roccaforte et al. } \\
(2000)\end{array}$ & USA & Case report & 1 & $\begin{array}{l}\text { Dementia, } \\
\text { type not } \\
\text { specified }\end{array}$ & Not stated & $\begin{array}{l}\text { Verbal } \\
\text { aggression } \\
\text { (disruptive } \\
\text { vocalizations) }\end{array}$ & $\begin{array}{l}\text { Improvement in } \\
\text { symptoms }\end{array}$ & None reported & [11] \\
\hline $\begin{array}{l}\text { Grant et al. } \\
(2001)\end{array}$ & USA & Case series & 4 & $A D$ & Bilateral & $\begin{array}{l}3 \text { - verbal and } \\
\text { physical } \\
\text { aggression } \\
1 \text { - verbal } \\
\text { aggression }\end{array}$ & $\begin{array}{l}\text { Improvement in } \\
\text { symptoms }\end{array}$ & None reported & [12] \\
\hline Reid (2006) & USA & Case report & 1 & Pick's disease & Not stated & $\begin{array}{l}\text { Verbal and } \\
\text { physical } \\
\text { aggression }\end{array}$ & No benefit & None stated & [13] \\
\hline $\begin{array}{l}\text { Sutor et al. } \\
(2008)\end{array}$ & USA & $\begin{array}{l}\text { Retrospective } \\
\text { chart review }\end{array}$ & 11 & $A D$ & $\begin{array}{l}8 \text { - bitemporal } \\
2 \text {-right } \\
\text { unilateral } 1 \text { - } \\
\text { bifrontal }\end{array}$ & $\begin{array}{l}\text { Verbal and } \\
\text { physical } \\
\text { aggression }\end{array}$ & $\begin{array}{l}\text { Nine of } 11 \\
\text { showed } \\
\text { improvement in } \\
\text { symptoms }\end{array}$ & $\begin{array}{l}7 \text {-no adverse } \\
\text { effects noted } \\
2 \text { - decreased } \\
\text { cognition } \\
1 \text {-somnolence and } \\
\text { atrial fibrillation } \\
\text { requiring } \\
\text { cardioversion } \\
1 \text { - urinary } \\
\text { retention }\end{array}$ & [14] \\
\hline $\begin{array}{l}\text { Bang et al. } \\
(2008)\end{array}$ & USA & Case reports & 2 & $\begin{array}{l}1-\mathrm{AD} \text { and } \\
\text { Parkinson's } \\
\text { disease } \\
1-\text { congenital } \\
\text { hydrocephalus }\end{array}$ & Bilateral & $\begin{array}{l}\text { Verbal } \\
\text { aggression } \\
\text { (disruptive } \\
\text { vocalizations) }\end{array}$ & $\begin{array}{l}\text { Improvement in } \\
\text { symptoms }\end{array}$ & None noted & [15] \\
\hline Wu et al. (2010) & USA & Case reports & 2 & $\begin{array}{l}1-\mathrm{AD} \\
1-\mathrm{FTD}\end{array}$ & Bitemporal & $\begin{array}{l}\text { Physical } \\
\text { aggression }\end{array}$ & $\begin{array}{l}\text { Improvement in } \\
\text { symptoms }\end{array}$ & None noted & [16] \\
\hline $\begin{array}{l}\text { Ujkaj et al. } \\
(2012)\end{array}$ & USA & $\begin{array}{l}\text { Retrospective } \\
\text { chart review }\end{array}$ & 16 & $\begin{array}{l}8-A D \\
3-V D \\
2-F T D \\
3-\text { unspecified } \\
\text { dementia }\end{array}$ & $\begin{array}{l}12 \text { - bilateral } \\
4 \text {-right } \\
\text { unilateral }\end{array}$ & $\begin{array}{l}\text { Verbal and } \\
\text { physical } \\
\text { aggression }\end{array}$ & $\begin{array}{l}15 \text { of the } 16 \\
\text { patients showed } \\
\text { improvement in } \\
\text { symptoms }\end{array}$ & $\begin{array}{l}8 \text { - transient } \\
\text { postictal confusion } \\
2 \text { - more severe } \\
\text { postictal confusion } \\
\text { No other serious } \\
\text { adverse effects } \\
\text { noted }\end{array}$ & [17] \\
\hline $\begin{array}{l}\text { Kramer et al. } \\
(2013)\end{array}$ & $\begin{array}{l}\text { The } \\
\text { Nether- } \\
\text { lands }\end{array}$ & Case series & 3 & $A D$ & Bilateral & $\begin{array}{l}\text { Verbal and } \\
\text { physical } \\
\text { aggression }\end{array}$ & $\begin{array}{l}\text { Improvement in } \\
\text { target behaviors }\end{array}$ & $\begin{array}{l}\text { No serious adverse } \\
\text { effects noted }\end{array}$ & [18] \\
\hline $\begin{array}{l}\text { Aksay et al. } \\
(2014)\end{array}$ & Germany & Case report & 1 & $A D$ & Right unilateral & $\begin{array}{l}\text { Verbal and } \\
\text { physical } \\
\text { aggression }\end{array}$ & $\begin{array}{l}\text { Improvement in } \\
\text { target behaviors }\end{array}$ & $\begin{array}{l}\text { No serious adverse } \\
\text { effects noted, } \\
\text { headaches after } \\
\text { first three sessions }\end{array}$ & [19] \\
\hline $\begin{array}{l}\text { Tang et al. } \\
\text { (2014) }\end{array}$ & USA & $\begin{array}{l}\text { Retrospective } \\
\text { chart review }\end{array}$ & 42 & $\begin{array}{l}\text { Dementia, } \\
\text { type not } \\
\text { specified }\end{array}$ & $\begin{array}{l}\text { Right unilateral } \\
\text { and bifrontal }\end{array}$ & Agitation & $\begin{array}{l}\text { Not noted in the } \\
\text { abstract }\end{array}$ & $\begin{array}{l}\text { Not noted in the } \\
\text { abstract }\end{array}$ & $\begin{array}{r}\text { [20] } \\
\text { (Ab- } \\
\text { stract } \\
\text { only) }\end{array}$ \\
\hline $\begin{array}{l}\text { Dare et al. } \\
(2015)\end{array}$ & USA & Case series & 1 & $A D$ & $\begin{array}{l}\text { Bilateral and } \\
\text { right unilateral }\end{array}$ & $\begin{array}{l}\text { Behavioral } \\
\text { dyscontrol }\end{array}$ & $\begin{array}{l}\text { Improvement in } \\
\text { target behaviors }\end{array}$ & None noted & [21] \\
\hline $\begin{array}{l}\text { Fàzzari et al. } \\
\text { (2015) }\end{array}$ & Italy & Case report & 1 & $A D$ & $\begin{array}{l}\text { Bifrontal and } \\
\text { bitemporal }\end{array}$ & $\begin{array}{l}\text { Restlessness, } \\
\text { mood liability } \\
\text { and verbal } \\
\text { aggression }\end{array}$ & $\begin{array}{l}\text { Improvement in } \\
\text { target behaviors }\end{array}$ & None noted & [22] \\
\hline
\end{tabular}


Table 1. Summary of published studies on the use of electroconvulsive therapy for the management of behavioral and psychological symptoms of dementia (cont.).

\begin{tabular}{|c|c|c|c|c|c|c|c|c|c|}
\hline Study (year) & Country & Type of study & $\begin{array}{l}\text { Number of } \\
\text { patients }\end{array}$ & $\begin{array}{l}\text { Type of } \\
\text { patients }\end{array}$ & Type of ECT & Target behaviors & Outcomes & Adverse effects & Ref. \\
\hline $\begin{array}{l}\text { Acharya et al. } \\
\text { (2015) }\end{array}$ & USA & $\begin{array}{l}\text { Prospective } \\
\text { cohort study }\end{array}$ & 23 & $\begin{array}{l}13-A D \\
4-V D \\
1-F T D \\
2-\text { mixed } \\
\text { dementia } \\
3-\text { unspecified } \\
\text { dementia }\end{array}$ & $\begin{array}{l}\text { Right unilateral } \\
\text { and bifrontal }\end{array}$ & $\begin{array}{l}\text { Agitation or } \\
\text { aggression }\end{array}$ & $\begin{array}{l}21 \text { out of the } 23 \\
\text { participants } \\
\text { responded to } \\
\text { treatment with } \\
\text { improvement in } \\
\text { symptoms }\end{array}$ & $\begin{array}{l}21 \text { out of the } 23 \\
\text { participants } \\
\text { tolerated the } \\
\text { treatments well, } \\
\text { two participants } \\
\text { developed post ECT } \\
\text { delirium, } \\
\text { one participant } \\
\text { developed atrial } \\
\text { fibrillation but } \\
\text { continued to } \\
\text { receive ECT }\end{array}$ & [23] \\
\hline $\begin{array}{l}\text { Zhang et al. } \\
(2016)\end{array}$ & China & $\begin{array}{l}\text { Case-control } \\
\text { study }\end{array}$ & 23 & $\begin{array}{l}8-A D \\
8-V D \\
4-F T D \\
3-\text { unspecified } \\
\text { dementia }\end{array}$ & Bitemporal & $\begin{array}{l}16 \text { - high risk for } \\
\text { suicide } \\
6 \text { - high risk for } \\
\text { aggression } \\
1-\text { insufficient } \\
\text { response to } \\
\text { pharmacother- } \\
\text { apy or } \\
\text { intolerable } \\
\text { adverse effects }\end{array}$ & $\begin{array}{l}21 \text { out of the } 23 \\
\text { participants } \\
\text { responded to } \\
\text { treatment with } \\
\text { improvement in } \\
\text { symptoms }\end{array}$ & $\begin{array}{l}7 \text { - transient } \\
\text { memory } \\
\text { impairment } \\
1 \text { - headache } \\
1 \text { - myalgia } \\
1 \text { - mild dyspnea } \\
1 \text { - transient } \\
\text { hypertension }\end{array}$ & [24] \\
\hline $\begin{array}{l}\text { Isserles et al. } \\
(2017)\end{array}$ & Canada & $\begin{array}{l}\text { Retrospective } \\
\text { chart review }\end{array}$ & 25 & $\begin{array}{l}11-A D \\
5-V D \\
4-L B D \\
3-F T D \\
9-\text { unspecified } \\
\text { dementia } \\
3-\text { mixed (A+ } \\
\text { VD) }\end{array}$ & $\begin{array}{l}\text { Bitemporal } \\
\text { Right unilateral } \\
\text { to bitemporal-3 } \\
\text { Bitemporal to } \\
\text { right } \\
\text { unilateral-1 }\end{array}$ & $\begin{array}{l}\text { Severe and } \\
\text { resistant BPSD }\end{array}$ & $\begin{array}{l}72 \%-\text { marked } \\
\text { response for } \\
\text { acute treatment } \\
\text { course } \\
87 \%-\text { marked } \\
\text { response for } \\
\text { maintenance } \\
\text { course }\end{array}$ & $\begin{array}{l}\text { Clinical note } \\
7 \% \text { - significant } \\
\text { cognitive adverse } \\
\text { effects in acute } \\
\text { course } \\
13 \% \text { - significant } \\
\text { cognitive adverse } \\
\text { effects in the } \\
\text { maintenance course } \\
\text { Attending } \\
\text { psychiatrist score } \\
21 \% \text { - significant } \\
\text { cognitive adverse } \\
\text { effects }\end{array}$ & [25] \\
\hline Lau et al. (2017) & Canada & $\begin{array}{l}\text { Retrospective } \\
\text { chart review }\end{array}$ & 5 & $\begin{array}{l}3-A D \\
2-\text { mixed } \\
\text { dementia (AD } \\
+V D)\end{array}$ & Bitemporal & $\begin{array}{l}\text { Verbal } \\
\text { aggression } \\
\text { (disruptive } \\
\text { vocalizations) }\end{array}$ & $\begin{array}{l}\text { Improvement in } \\
\text { target behaviors } \\
(p<0.0001)\end{array}$ & $\begin{array}{l}1 \text { - transient post } \\
\text { ECT delirium }\end{array}$ & [26] \\
\hline $\begin{array}{l}\text { Burton et al. } \\
(2017)\end{array}$ & USA & $\begin{array}{l}\text { Prospective } \\
\text { observational } \\
\text { study }\end{array}$ & 6 & $\begin{array}{l}3-A D \\
2-V D \\
1-\text { unspecified } \\
\text { dementia }\end{array}$ & Bitemporal & $\begin{array}{l}\text { Severe } \\
\text { behavioral } \\
\text { disturbances }\end{array}$ & $\begin{array}{l}\text { Improvement in } \\
\text { target behaviors }\end{array}$ & $\begin{array}{l}0 \text { - adverse events } \\
\text { necessitating ECT } \\
\text { discontinuation. } \\
1 \text { - post-ECT } \\
\text { nausea, remitted } \\
\text { with intravenous } \\
\text { ondansetron } \\
1 \text { - post-emergence } \\
\text { agitation, resolved } \\
\text { with intravenous } \\
\text { diazepam }\end{array}$ & [27] \\
\hline $\begin{array}{l}\text { Selvadurai et al. } \\
(2018)\end{array}$ & Canada & Case report & 1 & $\begin{array}{l}\text { Frontolobar } \\
\text { degeneration }\end{array}$ & Bitemporal & $\begin{array}{l}\text { Physical } \\
\text { aggression and } \\
\text { inappropriate } \\
\text { sexual behaviors }\end{array}$ & $\begin{array}{l}\text { Improvement in } \\
\text { target behaviors }\end{array}$ & None reported & [28] \\
\hline
\end{tabular}

\section{Conclusion \& future perspective}

As the available evidence for the use of non-pharmacological treatment modalities for the management of BPSD is strong, additional well-controlled and larger trials on the use of such treatments are expected in the near future. Given the strength of existing evidence, regulatory authorities will require that non-pharmacological treatment modalities must be tried among individuals with BPSD, before embarking on pharmacotherapeutic trials given the concern over adverse-effect profiles of these medications. There is growing literature on the use of ECT for 
the management of BPSD. Available evidence indicates that ECT is effective and well tolerate among individuals with BPSD. However, the evidence is limited to uncontrolled trails and to a limited number of individuals. As there is significant concern for the use of pharmacotherapeutic agents among individuals with BPSD, and the evidence for the use of ECT among individuals with BPSD is growing, well controlled and larger trials of the use of ECT for the management of BPSD can be anticipated in the near future. If the evidence from these new trials is robust and confirms the findings that ECT is well tolerated and beneficial to individuals with BPSD, ECT will have a definitive place among management strategies for BPSD. However, given the public perception of ECT, it is difficult to envisage the use of ECT among individuals with BPSD except in refractory cases or in cases where the response to other treatments is slow or limited by tolerability issues.

\section{Financial \& competing interests disclosure}

The authors have no relevant affiliations or financial involvement with any organization or entity with a financial interest in or financial conflict with the subject matter or materials discussed in the manuscript. This includes employment, consultancies, honoraria, stock ownership or options, expert testimony, grants or patents received or pending, or royalties.

No writing assistance was utilized in the production of this manuscript.

\section{References}

1. Tampi RR, Williamson D, Muralee S et al. Behavioral and psychological symptoms of dementia: part I-epidemiology, neurobiology, heritability, and evaluation. Clin. Geriatrics 19, 41-46 (2011).

2. Tampi RR, Williamson D, Muralee $S$ et al. Behavioral and psychological symptoms of dementia: part II treatment. Clin. Geriatrics 19, 31-40 (2011).

3. Livingston G, Johnston K, Katona C et al. Systematic review of psychological approaches to the management of neuropsychiatric symptoms of dementia. Am. J. Psych. 162, 1996-2021 (2005).

4. Mittal V, Kurup L, Williamson D, Muralee S, Tampi RR. Risk of cerebrovascular adverse events and death in elderly patients with dementia when treated with antipsychotic medications: a literature review of evidence. Am. J. Alz. Dis. Other Demen. 26, 10-28 (2011).

5. van der Wurff FB, Stek ML, Hoogendijk WJ, Beekman AT. The efficacy and safety of ECT in depressed older adults: a literature review. Int. J. Geriatr. Psych. 18(10), 894-904 (2003).

6. Meyer JP, Swetter SK, Kellner CH. Electroconvulsive therapy in geriatric psychiatry: a selective review. Psychiatr. Clin. North Am. 41(1), 79-93 (2018).

7. McDonald WM. Neuromodulation treatments for geriatric mood and cognitive disorders. Am. J. Geriatr. Psych. 24(12), 1130-1141 (2016).

8. Burgut FT, Popeo D, Kellner CH. ECT for agitation in dementia: is it appropriate? Med. Hypotheses 75(1), 5-6 (2010).

9. Carlyle W, Killick L, Ancill R. ECT: an effective treatment in the screaming demented patient. J. Am. Geriatr. Soc. 39 (6), 637 (1991).

10. Holmberg SK, Tariot PN, Challapalli R. Efficacy of ECT for agitation in dementia: a case report. Am. J. Geriatr. Psych. 4(4), 330-334 (1996).

11. Roccaforte WH, Wengel SP, Burke WJ. ECT for screaming in dementia. Am. J. Geriatr. Psych. 8(2), 177 (2000).

12. Grant JE, Mohan SN. Treatment of agitation and aggression in four demented patients using ECT. J. ECT 17(3), 205-209 (2001).

13. Reid C. Medicating "Margaret". J. Clin. Ethics 17(4), 340-343 (2006).

14. Sutor B, Rasmussen KG. Electroconvulsive therapy for agitation in Alzheimer disease: a case series. J. ECT 24(3), 239-241 (2008).

15. Bang J, Price D, Prentice G, Campbell J. ECT treatment for two cases of dementia-related pathological yelling. J. Neuropsych. Clin. Neurosci. 20(3), 379-380 (2008).

16. Wu Q, Prentice G, Campbell JJ. ECT treatment for two cases of dementia-related aggressive behavior. J. Neuropsych. Clin. Neurosci. 22(2), E10-E11 (2010).

17. Ujkaj M, Davidoff DA, Seiner SJ, Ellison JM, Harper DG, Forester BP. Safety and efficacy of electroconvulsive therapy for the treatment of agitation and aggression in patients with dementia. Am. J. Geriatr. Psych. 20(1), 61-72 (2012).

18. Kramer BL, Albronda T, Clarenbach-Wierda DL. Electro-convulsive treatment of elderly patients with both behavioral problems and dementia. Tijdschr. Psychiatr. 55(12), 949-953 (2013).

19. Aksay SS, Hausner L, Frölich L, Sartorius A. Severe agitation in severe early-onset Alzheimer’s disease resolves with ECT neuropsychiatr. Dis. Treat. 10, 2147-2151 (2014).

20. Tang Y, Herminda A, Khanh H, Laddha SR, McDonald WM. Efficacy and safety of ECT for behavioral and psychological symptoms of dementia (BPSD): a retrospective chart review. Am. J. Geriatr. Psych. 22(3), S114-S115 (2014).

21. Dare FY, Rasmussen KG. Court-approved electroconvulsive therapy in patients unable to provide their own consent: a case series. J. ECT 31(3), 147-149 (2015). 
22. Fàzzari G, Marangoni C, Benzoni O, Maintenance ECT. for the treatment and resolution of agitation in Alzheimer’s dementia. J. Psychopathol. 21, 159-160 (2015).

23. Acharya D, Harper DG, Achtyes ED et al. Safety and utility of acute electroconvulsive therapy for agitation and aggression in dementia. Int. J. Geriatr. Psych. 30(3), 265-273 (2015).

24. Zhang QE, Sha S, Ungvari GS et al. Demographic and clinical profile of patients with dementia receiving electroconvulsive therapy: a case-control study. J. ECT 32(3), 183-186 (2016).

25. Isserles M, Daskalakis ZJ, Kumar S, Rajji TK, Blumberger DM. Clinical effectiveness and tolerability of electroconvulsive therapy in patients with neuropsychiatric symptoms of dementia. J. Alzheimers Dis. 57(1), 45-51 (2017).

26. Lau TE, Babani PK, McMurray LA. The treatment of disruptive vocalization in dementia (behavioral and psychological symptoms of dementia) with electroconvulsive therapy: a case series. J. ECT 33(2), e9-e13 (2017).

27. Burton MC, Koeller SL, Brekke FM, Afonya AT, Sutor B, Lapid MI. Use of electroconvulsive therapy in dementia-related agitation: a case series. J. ECT 33(4), 286-289 (2017).

28. Selvadurai MI, Waxman R, Ghaffar O, Fischler I. Efficacy and safety of maintenance electroconvulsive therapy for sustaining resolution of severe aggression in a major neurocognitive disorder. BMJ Case Rep. 2018, doi:10.1136/bcr-2017-222100 (2018).

29. Mcllroy S, Craig D. Neurobiology and genetics of behavioural syndromes of Alzheimer's disease. Curr. Alzheimer Res. 1(2), 135-142 (2004).

30. Tascone LDS, Bottino CMC. Neurobiology of neuropsychiatric symptoms in Alzheimer's disease: a critical review with a focus on neuroimaging. Dement. Neuropsychol. 7(3), 236-243 (2013).

31. Devanand DP, Shapira B, Petty F et al. Effects of electroconvulsive therapy on plasma GABA. Convuls. Ther. 11(1), 3-13 (1995).

32. Mann JJ. Neurobiological correlates of the antidepressant action of electroconvulsive therapy. J. ECT 14(3), 172-180 (1998).

33. Newman ME, Gur E, Shapira B, Lerer B. Neurochemical mechanisms of action of ECS: evidence from in vivo studies. J. ECT 14(3), 153-171 (1998).

34. Glass OM, Forester BP, Hermida AP. Electroconvulsive therapy (ECT) for treating agitation in dementia (major neurocognitive disorder) - a promising option. Int. Psychogeriatr. 29(5), 717-726 (2017).

35. van den Berg JF, Kruithof HC, Kok RM, Verwijk E, Spaans HP. Electroconvulsive therapy for agitation and aggression in dementia: a systematic review. Am. J. Geriatr. Psych. 26(4), 419-434 (2018).

36. Osler M, Rozing MP, Christensen GT, Andersen PK, Jørgensen MB. Electroconvulsive therapy and risk of dementia in patients with affective disorders: a cohort study. Lancet Psych. 5(4), 348-356 (2018).

37. Chu CW, Chien WC, Chung CH et al. Electroconvulsive therapy and risk of dementia - a nationwide cohort study in Taiwan. Front. Psych. 9, 397 (2018).

38. Rao V, Lyketsos CG. The benefits and risks of ECT for patients with primary dementia who also suffer from depression. Int. J. Geriatr. Psych. 15(8), 729-735 (2000).

39. Oudman E. Is electroconvulsive therapy (ECT) effective and safe for treatment of depression in dementia? A short review. J. ECT 28(1), 34-38 (2012)

40. Hausner L, Damian M, Sartorius A, Frölich L. Efficacy and cognitive side effects of electroconvulsive therapy (ECT) in depressed elderly inpatients with coexisting mild cognitive impairment or dementia. J. Clin. Psych. 72(1), 91-97 (2011). 